\title{
Isolation, Cultural and Morphological Characterization of Alternaria dauci causing Alternaria Leaf Blight of Carrot
}

\author{
V. Prasanna Krishna ${ }^{1 *}$, A.P. Suryawanshi ${ }^{2}$, Satyadev Prajapati ${ }^{2}$ and S. Surekha ${ }^{2}$ \\ College of Agriculture, Latur, VNMKV, Parbhani, India \\ *Corresponding author
}

\section{A B S T R A C T}

\section{Keywords \\ Alternaria dauci, Carrot, Carrot leafblight, Alternaria spp, Cultural characteristic, Morphological characteristic \\ Article Info \\ Accepted: \\ 07 November 2018 \\ Available Online: \\ 10 December 2018}

Alternaria dauci affected leaves of carrot crop collected from farmers field and Isolated on Potato dextrose agar (PDA) produced profuse growth, olivaceous/greenish-brown to black, flat mycelial growth, irregular to circular shaped colony with smooth margins, flat elevation, thick texture, poor zonation and good to excellent sporulation. Morphological characteristics of Alternaria dauci, revealed septate mycelium, dark brown muriform conidia of the size 45-70 x 10-22 $\mu \mathrm{m}$. and the beak measured of 30-120 $\mu \mathrm{m}$. The conidia possessed about 3-7 horizontal and 1-2 vertical septa and the conidiophores measured about $28-85 \mu \mathrm{m}$ in length and $5.0 \mu \mathrm{m}$ in breadth.

\section{Introduction}

Carrot (Dacus carota L.) belongs to the family Apiaceae (Umbelliferae), native of temperate regions of Europe, southwest Asia and naturalized to North America and Australia. The Asiatic carrot was developed from the Afghan type and a red type appeared in India around the 1700s. Carrot occupies a prime position among the winter vegetables. Carrots are being increasingly consumed, mainly due to their pleasant flavour and perceived healthy benefits related to vitamins, minerals and fiber content. Furthermore, carrots are rich in dietary fiber, antioxidants, minerals and fall in alkaline fruit. Carrots contain minerals such as Calcium (39mg), Phosphorus (26 mg), Sodium (32 mg), Potash (102 mg), and Ferrous/Iron (1.4 mg) per 100g fresh weight. Carrots are rich in vitamins (B1, B2, B3, B6) and abundant of $\beta$-carotene, a dimmer of vitamin A. Along with traditional antioxidants like vitamin $\mathrm{C}$, carrot contains poly-nutrient antioxidant ( $\beta$-carotene), which protect human body from cancer of lungs, stomach, colon, cervix, uterus and oral cavity. Vitamin A in carrot prevents night blindness and also combact muscular degeneration. Eating more 
carrots can reduce the risk of cardiovascular disease, by lowering down cholesterol. It helps to manage metabolic processes and functioning of immune system. Eating carrot is also good for allergies, anemia, rheumatism and tonic for nervous system (Hanif et al., 2006; Fabiyi et al., 2015). The polyphenols and vitamins present in carrot act as antioxidants, anticarcinogens and immunoenhancers, anti-diabetic, cholesterol and cardio-vascular disease lowering, antihypertensive, hepatoprotective, renoprotective, wound healing, anti-bacterial, anti-fungal and anti-inflammatory (Verma et al., 2013; Koley et al., 2013, Dias, 2014). The production and productivity of the carrot crop seems to be hampered due to several biotic and abiotic agents. Among the biotic agents, Alternaria leaf blight/spot caused by A. dauci is one of the major threats causing serious damage to carrot crop and yield losses of about 45-60 percent (Gugino et al., 2004; Chand and Singh 2011; Bhatrath et al., 2012; Castillo et al., 2013). Alternaria leaf blight (A. dauci) is one of the most important foliar diseases of carrot and occurs worldwide. Other than $A$. dauci the Alternaria spp. reported to infect carrot are A. alternata and $A$. tenuissima and A. radicina (Stranberg, 1992; Tulek and Dolar, 2015). Among these most widespread and frequent are A. dauci and A. radicina, inducing leaf blight/leaf spot and block rot diseases, respectively in carrot crop (Davis and Raid, 2002; Koike et al., 2009; Tulek and Dolar, 2015). However, in India, A. dauci has been reported as frequent and common cause of Alternaria leaf blight/leaf spot of carrot (Chand and Singh, 2011; Bharat et al., 2012), causing $>60 \%$ yield losses.

The characteristic symptoms induced by $A$. dauci, causing Alternaria leaf blight disease in carrot are: small lesions commonly on margins and tips of carrot leaflets, initial symptoms appear on older leaves as irregularly-shaped, minute, dark brown-to-black spots, with yellow border on edge of the leaflets. Small, brown, water soaked spots appear on leaves and petiole and lesions often surrounded by a well defined yellow halo. Lesions on petioles are brown and irregular, which under favourable conditions increase in number and size, get coalesced exhibiting blighted (burned) appearance and eventually, such leaflets may shrivel and die. The pathogens can be transmitted through infected or contaminated seeds and can survive on crop residues, which act as a source of primary inoculum in subsequent cropping years. However, they cannot persist free in the soil for too long once the carrot tissues are thoroughly decomposed and the rate of spread of the diseases in the field is dependent on the initial level of inoculum available. Infection by Alternaria dauci is favoured by cool to moderate temperatures and prolonged leaf wetness. Infection can occur in 8 to 12 hours at temperatures of $16-25^{\circ} \mathrm{C}$, the fungus sporulates readily on dead necrotic tissues and the spores germinate readily in water droplets and dew (Delahaut and Stevenson, 2004; Gugino et al., 2004; Chand and Singh, 2011; Bharat et al., 2012; Tulek and Dolar, 2015).

\section{Materials and Methods}

\section{Disease samples}

Carrot crop leaflets exhibiting typical symptoms of leaf blight (Alternaria dauci) disease were collected in the paper bags from the standing carrot crops grown on farmer's fields and brought to the laboratory for further studies.

\section{Culture media}

Potato dextrose agar (PDA), the common laboratory culture medium was used as basal medium for isolation, purification, multiplication and maintenance of the pure culture of Alternaria dauci. Causing carrot leafblight. 


\section{Potato dextrose agar composition}

$\begin{array}{ll}\text { Peeled potato } & : 200 \mathrm{~g} \\ \text { Dextrose } & : 20 \mathrm{~g} \\ \text { Agar agar } & : 20 \mathrm{~g} \\ \text { Distilled water } & : 1000 \mathrm{ml}\end{array}$

\section{Collection of diseased sample}

Naturally leaf blight diseased specimen of carrot crop collected from farmers fields Visual observations were made for manifestation of typical symptoms of carrot leaf blight disease. Diseased carrot leaf blight specimens collected were washed in running tap water to remove extraneous material.

\section{Isolation}

Diseased leaf specimens were brought to the laboratory, washed thoroughly in running tap water, blot dried and cut with sharp sterilized blade into small bits $(5 \mathrm{~mm})$, keeping half healthy and half diseased portion intact and subjected to tissue isolation (Tuite, 1969). These pieces were surface sterilized with $0.1 \%$ aqueous solution of Mercuric chloride $\left(\mathrm{HgCl}_{2}\right)$ for two minutes, washed by giving three sequential changes with sterile distilled water in petriplates to remove traces of Mercuric chloride and blot dried. These were then inoculated on autoclaved and cooled PDA medium in sterilized glass Petri-plates, under aseptic conditions of Laminar-air-flow Cabinet (Make: ACS, Bangalore) and incubated in BOD incubator (Make: MAC, New Delhi) at $27 \pm 2^{0} \mathrm{C}$ temperature. Three to four days of incubation, profuse mycelial growth, free from any contaminant was obtained.

\section{Cultural and morphological characters}

Of the test pathogen (A. dauci) grown on PDA plates, cultural characteristics viz., radial mycelial growth / colony diameter; shape, colour, margin, texture, zonation, elevation etc. of the colony developed were recorded at seven days of incubation and sporulation, if any was recorded under Stereobinocu lar microscope (at 10X) at five different microscopic fields.

For studying morphological characteristics, temporary mounts of 10-12 days old pure culture of $A$. dauci on clean glass slide in a drop of Lactophenol cotton blue were prepared, covered with glass slide and mounted under research microscope. Observations on spore/conidia (colour, shape, size, septation) and conidiophores (colour, size) were recorded and measurements of the conidia and conidiophores were attempted under five different microscopic fields (400X), by using ocular micrometer, calibrated with stage micrometer.

\section{Pathogenicity test}

Surface sterilized $\left(0.1 \% \quad \mathrm{HgCl}_{2}\right)$ seeds of Carrot (Cv. Mahalakshmi) were sown (@10 seeds/pot) in the earthen pots $(30 \mathrm{~cm}$ dia.) filled with autoclaved potting mixture of soil: sand: FYM (2:1:1), watered regularly and kept in the screen house for further growth. After two weeks of seedling emergence, healthy growing two seedlings per pot were maintained by thinning out extra seedlings, watered these pots and maintained in screenhouse for further development. Sporecum-mycelial suspension of the test pathogen (A. dauci) was prepared by flooding $5-10 \mathrm{ml}$ distilled water on sporulating 10-12 days fresh and pure culture of the test pathogen on PDA plates.

The resultant spore-cum-mycelial suspension was filtered through double-layered muslin cloth and filtrate obtained was suitably diluted with sterile distilled water to get inoculums concentration of $2 \times 10^{6}$ spore $/ \mathrm{ml} \mathrm{spores} / \mathrm{ml}$. 
Thirty days old seedlings of Carrot $(\mathrm{Cv}$. Mahalakshmi) grown in earthen pots were artificially inoculated by spraying (hand automizer) with spore suspension $\left(2 \times 10^{6}\right.$ spore/ml) of the test pathogen, during evening hours and covered these with transparent polybags overnight. Seedlings sprayed with sterile water (without inoculum) were also maintained as uninoculated control. Both inoculated and uninoculated carrot seedling pots were incubated in the screenhouse, for further development of Alternaria blight disease symptoms. Observations on leaf blight/spots developed in respect of initiation of symptoms, incubation period, lesions colour frequency and shape etc. were recorded and compared these symptoms with naturally leaf blight diseased symptoms on carrot crop plants. From these artificially inoculated/diseased seedlings of carrot, the test pathogen was reisolated on PDA medium. After a week of incubation observed the cultural and morphological characteristics and compared them with pure culture characteristics of the test pathogen isolated from naturally leaf blight/spot diseased specimens of carrot crop.

\section{Results and Discussion}

\section{Visual observations}

Alternaria leaf blight diseased specimens of carrot crop collected from farmer's fields exhibited typical symptoms as: initially, irregularly shaped, minute, dark brown spots, with yellow coloured edge of the leaflet, which later expanded, turned brown and caused leaf blight.

Similar symptoms of carrot Alternaria leaf blight observed in present studies were also reported earlier by many workers. Minute, irregularly shaped, dark brown spots on margins and tips of leaflets were induced by A. dauci in carrot, causing blightening and death of leaflets (Wright and Champaign,
1990; Delahaut and Stevenson, 2004; Gugino et al., 2004; Soylu et al., 2005; Tulek and Dolar, 2015).

\section{Isolation of the pathogen}

Applying tissue isolation technique, the test fungus was isolated from naturally leaf blighted carrot specimens on Potato dextrose agar (PDA) medium, which yielded olivaceous/greenish-brown to black, flat mycelial growth (PLATE I) of the test fungus.

\section{Microscopic observations}

Microscopic examinations of the temporary mounts prepared of Alternaria diseased leaf tissues and pure culture of $A$. dauci (PLATE I) revealed olivaceous / greenish-brown coloured septate mycelium. Conidia were muriform, pale olivaceous-brown, 1-3 longitudinal and 59 transverse septa, with or without beak (PLATE II).

\section{Pathogenicity test}

The pathogenicity test attempted by spray inoculating the spore suspension $\left(2 \times 10^{6}\right.$ spores $/ \mathrm{ml}$ ) on carrot local cultivar seedlings revealed $A$. dauci as pathogenic to carrot crop, causing Alternaria leaf blight. The symptoms induced were irregularly shaped, minute, dark brown to black spots, with yellow colour on edge of the leaflet blade, which were exactly similar to those symptoms observed on naturally Alternaria leaf blight diseased carrot plants. Such typical symptoms visualized within a week of inoculation, with an average of 7-8 lesions per carrot seedlings.'

Reisolation from artificially diseased foliage of the carrot seedlings, consistently yielded typical A. dauci colony on PDA plates and its cultural and morphological characteristics were exactly similar with that of the pure culture obtained from naturally Alternaria leaf 
Table.1 Cultural and morphological characteristics of $A$. dauci, causing leaf blight of carrot

\begin{tabular}{|c|c|c|c|c|c|c|c|c|c|c|}
\hline Sr. & \multicolumn{10}{|c|}{ Parameters } \\
\hline 1 & \multicolumn{10}{|c|}{ Cultural/Colony characteristics } \\
\hline & $\begin{array}{c}\text { Growth } \\
(\mathrm{mm})\end{array}$ & Shape & Margin & \multicolumn{2}{|c|}{ Colour } & \multicolumn{3}{|c|}{ Elevation } & Texture & Zonation \\
\hline & 90.00 & Irregular & Smooth & $\begin{array}{r}\text { Olivar } \\
\text { bla }\end{array}$ & ous & \multicolumn{3}{|c|}{ Flat } & Thick & Poor \\
\hline \multirow[t]{4}{*}{2} & \multicolumn{10}{|c|}{ Morphological characteristics } \\
\hline & Colour & Shape & \multicolumn{6}{|c|}{ Conidia } & \multicolumn{2}{|c|}{ Conidiophores } \\
\hline & & & $\begin{array}{c}\text { Length } \\
(\mu \mathrm{m})\end{array}$ & $\begin{array}{c}\text { Breadth } \\
(\mu \mathrm{m})\end{array}$ & & gth & HS & VS & $\begin{array}{c}\text { Length } \\
\text { ( } \mu \mathrm{m})\end{array}$ & $\begin{array}{c}\text { Breadth } \\
\quad(\boldsymbol{\mu m})\end{array}$ \\
\hline & $\begin{array}{c}\text { Dark } \\
\text { brown }\end{array}$ & Muriform & $45-70$ & $10-22$ & & & $3-7$ & $1-2$ & $28-85$ & 5 \\
\hline
\end{tabular}

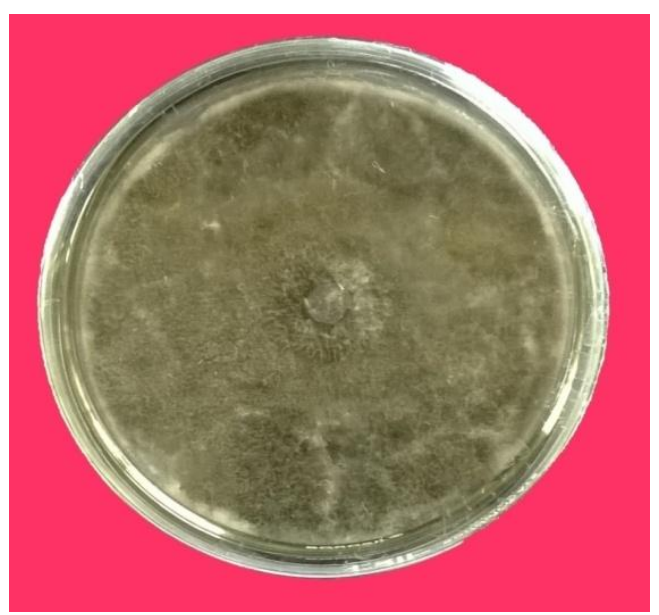

Plate.1 Pure culture of $A$. dauci isolated from leaf blighted carrot plants
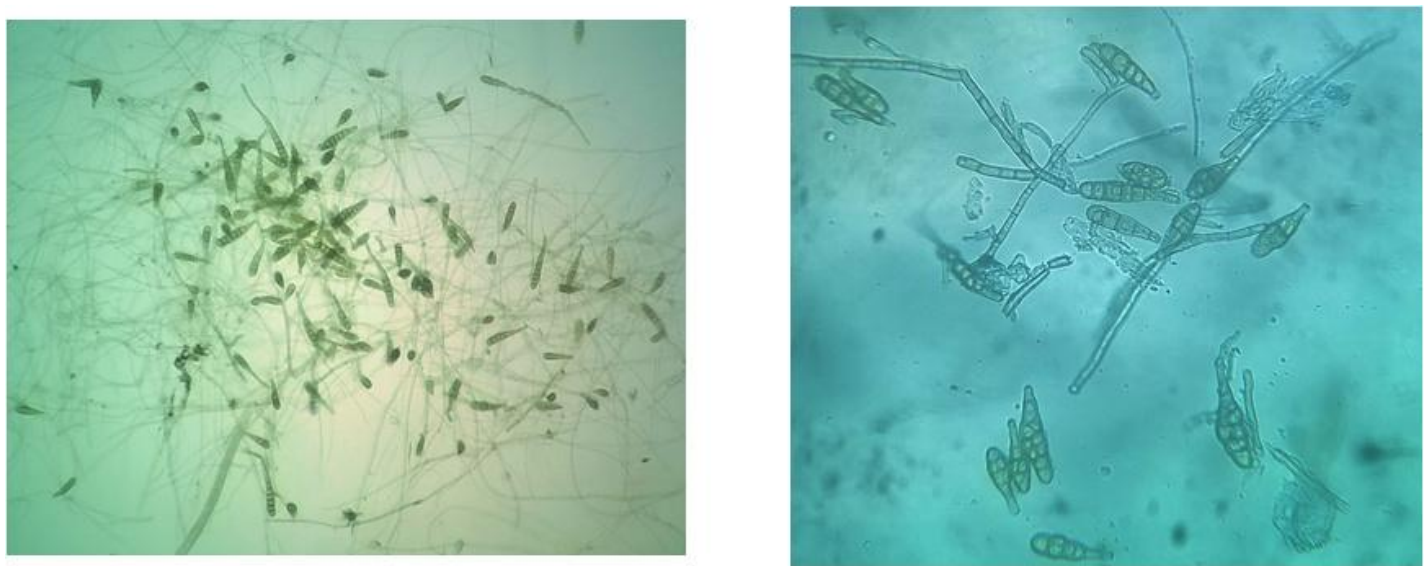

Plate.2 Microphotographs of mycelium and spores of A. dauci (400 X) 
blighted carrot plants. Thus, pathogenicity of A. dauci was proved by applying Koch's postulates.

Similarly, by employing spray inoculation of spore suspension on carrot seedlings and applying Koch's postulates, the pathogenicity of A. dauci in carrot (Soteros, 1979; Soylu et al., 2005; Mamgin et al., 2013; Tulek and Solar, 2015), were successfully attempted and proved earlier by several works.

\section{Identification of the pathogen}

Based on typical symptomatology, cultural and morphological characteristics, microscopic observations and pathogenicity test; the test pathogen was identified as Alternaria dauci (Khun) Groves and Skolko, and further confirmed by comparing its cultural and morphological characteristics with its authentic descriptions given by Rao, (1969), Simmions (1995), Soylu et al., (2005), Lopes and Martins (2008) and Tulek and Dolar (2015).

\section{Cultural and morphological characteristics}

Results (Table 1) revealed that A. dauci exhibited profuse growth $(90.00 \mathrm{~mm})$ on PDA plate. The colony colour was olivaceous green black, irregular to circular shaped colony with smooth margins, flat elevation, thick texture, poor zonation and good to excellent sporulation.

Morphological characteristics of A. dauci, revealed dark brown muriform conidia of the size 45-70 x 10-22 $\mu \mathrm{m}$. and the beak measured of $30-120 \mu \mathrm{m}$. The conidia possessed about 3-7 horizontal and 1-2 vertical septa and the conidiophores measured about $28-85 \mu \mathrm{m}$ in length and $5.0 \mu \mathrm{m}$ in breadth.

These results are in conformity with cultural and morphological characteristics of $A$. dauci (carrot leaf blight) reported earlier by many workers (Simmions, 1995; Soylu et al., 2005; Lopes and Martins, 2008; Bharth et al., 2012; Tulek and Dolar, 2015).

\section{References}

Bharath, N. K., Kumar, R. and Gupta, P. (2012). Two new diseases on carrot seed crop in dry temperate zone of Himachal Pradesh. Int. J. Farm Sci. 2(2):44-47.

Castillo, H. F. D., Reyes, C. F., Morales, G. G., Herrera, R. R. and Aguilar, C. (2013). Biological control of carrot pathogens by plant-growth promoting Bacillus spp. http://dx.doi.org/10.5772/54229.

Chand, G. and Singh, V. K. (2011). Ecofriendly management of Alternaria blight of carrot (Dacus carota L.). J. Hill Agri. 2(2):201-203.

Davis, R. M. and Raid, R. N., 2002. Crown, root, and wilt diseases. Compendium of Umbelliferous Crop Diseases, Pp : 25 40.

Delahaut, K. and Stevenson. W (2004). Carrot diseases: Alternaria and Cercospora leaf blights. Cooperative Extension Pub. Univ. Wisconsin. A38.

Dias, J. C. S. (2014).Nutritional and health benefits of carrots and their seed extracts. Food and Nutrition Sci. 5(2): 2147-2156.

Fabiyi, E.F., Abubakar, B.Z., Yahaya, A.T., Yakubu, A.A. and Yakubu, D.H. (2015). Carrot intake its perception, nutritional value and health benefits: a case study of Sokoto Metropolis, Sokoto State, Nigeria. Pak. J. Nutr. 14 (3): 136-140

Gugino, B. K., Carroll, J., Chen, J., Ludwig, J. and Abawi, G. (2004). Carrot leaf blight disease management in New York. www.nysipm.cornell.edu.

Hanif, R., Iqbal, Z., Iqbal, M., Hanif, S. and Rasheed, M. (2006). Use of vegetables 
as nutritional food: Role in human health. J. Agric. Biol. Sci. 1(1):186-189.

Koike S.T., Gladders, P. and Paulus, A.O. (2009). Vegetable diseases, a color handbook. Academic Press. Third edition, Boston. pp. 448.

Koley, T. K., Singh, S., Khemariya, P., Sarkar, A., Kaur, C., Chaurasia, S. N. S. and Naik, P. S. (2013). Evaluation of bioactive properties of Indian carrot (Daucus carota L.): A chemometric approach. Food Res. Int. 3(5):25-129.

Lopes, M. C. and Martins, V.C. (2008). Fungal plant pathogens in Portugal: Alternaria dauci. Rev. Iberoam. Micol. 25: 254-256.

Mamgain, A., Roychowdhury, R. and Tah, J. (2013). Alternaria pathogenicity and its strategic controls. Res. J. Biol. 1: 01-09.

Rao, V. G. (1963). The fungus genus Alternaria in Bombay-Maharashtra-I. www.biologiezentrum.at.

Simmons, E. G. (1995). Alternaria themes and variations (122-144). Mycotaxon. 55:55-163.

Soteros, I. J. (1979). Pathogenicity and control of Alternaria radicina and $A$. dauci in carrots. N.Z. J. Agri. Res. 22: 191-196.
Soylu, S., Kurt, S., Soylu, E. M. and Tok, F. M. (2005).First reported of Alternaria leaf blight caused by Alternaria dauci on carrot in Turkey.Pl. Pathol.54:252.

Strandberg, J.O. (1992). Alternaria species that attack vegetable crops: Biology and options for disease management. In: Alternaria: Biology, plant disease and metabolites. (Cielkowski, J. and Viscontia A. eds). Amsterdam: Elsevier Science Pub. P. 367-398.

Tuite, J. (1969). Plant Pathological Methods. Fungi and Bacteria. Minneapolis, Minnesota. USA. Burgess Publishing Company. pp. 239.

Tulek, S. and Dolar, F. S. (2015) Detection and identification of Alternaria species causing diseases of carrot in Ankara province, Turkey. Scientific Papers. Series B, Horticulture. LIX : 263-268.

Verma, S., Yadav, A., Jat, G., Gothwal, R. K. and Singh, J. (2013). Cultivation of carrot (Dacus carota) under organic farming in India. Popular Kheti. 1(4):203-206.

Wright, St. and Champaign, I. L. (1990). Leaf blights or spots of carrot. University of Illinois extension. RDP No.938.

\section{How to cite this article:}

Prasanna Krishna, V., A.P. Suryawanshi, Satyadev Prajapati and Surekha, S. 2018. Isolation, Cultural and Morphological Characterization of Alternaria dauci causing Alternaria Leaf Blight of Carrot. Int.J.Curr.Microbiol.App.Sci. 7(12): 754-760.

doi: https://doi.org/10.20546/ijcmas.2018.712.093 